\title{
KETERKAITAN ANTARA MOTIVASI, KEPERCAYAAN, NORMA SUBYEKTIF, SIKAP TERHADAP NIAT UNTUK BERBAGI PENGETAHUAN
}

\author{
Tantri Yustina \\ Program Pascasarjana Universitas Sebelas Maret Surakarta. \\ J1. Ir. Sutami36 A Surakarta. tanzhu_yus@yahoo.com
}

\begin{abstract}
The purpose of this study is to examine and analyze the effect of extrinsic motivation, intrinsic motivation, subjective norms, trust, and attitudes toward intention for sharing knowledge. Type of the research in this study is a quantitative reserch, by taking samples 200 respondents at SMP Muhammadiyah and MTs Muhammadiyah at Sukoharjo. The technique of collecting data uses questionnaires, and tested uses structural equation model/Structural Equation Modelling (SEM). The results of this study show that extrinsic motivation and intrinsic motivation has no effect on the intention to share knowledge, extrinsic motivation and intrinsic motivation effect on attitudes and trust, trust and subjective norms effect on attitudes and attitudes, and subjective norms effect on the intention for sharing knowledge.
\end{abstract}

Keywords: Motivation, subjective norms, beliefs, and attitudes toward the intention for sharing knowledge

\begin{abstract}
Abstrak
Penelitian ini untuk menguji dan menganalisis pengaruh motivasi ekstrinsik, motivasi instrinsik, norma subyektif, kepercayaan, dan sikap terhadap niat untuk berbagi pengetahuan. Jenis penelitian ini adalah kuantitatif, dengan mengambil sampel di SMP Muhammadiyah dan MTs Muhammadiyah Sekabupaten Sukoharjo dengan jumlah sampel 200 responden. Teknik pengumpulan data menggunakan kuesioner, dan diuji menggunakan model persamaan struktural/Structural Equation Modelling (SEM). Hasil penelitian menunjukkan bahwa motivasi ekstrinsik dan motivasi intrinsik tidak berpengaruh pada niat untuk berbagi pengetahuan, motivasi ekstrinsik dan motivasi intrinsik berpengaruh pada sikap dan kepercayaan, kepercayaan dan norma subyektif berpengaruh pada sikap, dan kepercayaan, sikap, dan norma subyektif berpengaruh pada niat untuk berbagi pengetahuan.
\end{abstract}

Kata kunci: motivasi, norma subyektif, kepercayaan, dan sikap niat berbagi pengetahuan

\section{Pendahuluan}

Niat untuk berbagi pengetahuan oleh anggota organisasi itu penting untuk dilakukan karena selain menguntungkan bagi organisasi dapat juga meningkatkan kesejahteraan bagi anggota serta semua yang bersangkutan dengan instansi tersebut. Namun, pencapaian tujuan ini tidak mudah untuk dilakukan karena berbagi pengetahuan terdapat faktor-faktor yang mempengaruhinya. Faktor-faktor yang mempengaruhinya, antara lain sikap. Sikap menjadi satu bagian yang dianggap penting. 
Sikap atau perilaku merupakan hasil dari kombinasi niat dan kemauan untuk melakukan tujuan.

Motivasi juga merupakan faktor yang menentukan bagaimana niat untuk berbagi pengetahuan antar anggota organisasi. Motivasi terdiri dari motivasi ekstrinsik dan intnsik. motivasi ekstrinsik untuk berbagi pengetahuan adalah keyakinan hasil yang biasanya didasarkan pada persepsi karyawan dari nilai hubungan dengan pertukaran pengetahuan. Dalam konteks berbagi pengetahuan, biaya termasuk faktor yang berhubungan dengan upaya (misal waktu yang dibutuhkan, usaha mental) sedangkan potensi keuntungan termasuk menerima imbalan organisasi atau menciptakan kewajiban bagi rekan-rekan untuk membalas. Sedangkan motivasi intrinsik berhubungan erat dengan berbagi pengetahuan hal ini dapat dilihat dari ketertarikan atau kesenangan bahkan kepuasan dari anggota organisasi.

Faktor lain yang mempengaruhi niat untuk berbagi pengetahuan oleh anggota organisasi yaitu kepercayaan. Kepercayaan merupakan bagian dari niat untuk berbagi pengetahuan. Kepercayaan antar pribadi adalah keadaan psikologis yang terdiri dari niat seseorang untuk menerima kerentanan terhadap tindakan pihak lain. Hal lain yang dapat mempengaruhi berbagi pengetahun lainnya adalah adanya norma subyektif. Menurut Ibragimova, et, al. (2012), norma subyektif dipandang sebagai kombinasi dari harapan dirasakan dari individu atau kelompok yang relevan bersama dengan niat untuk mematuhi harapan tersebut. Dengan kata lain, "persepsi orang bahwa kebanyakan orang yang penting bagi dia pikir dia harus atau tidak harus melakukan perilaku yang bersangkutan".

Feng Lin (2007) menjelaskan adanya hubungan antara motivasi kerja (ekstinsik dan intrinsik) dan niat untuk berbagi pengetahuan. Dalam penelitian itu diketahui bahwa berbagi pengetahuan memiliki hubungan positif maupun negatif dengan beberapa faktor tersebut. Karena tidak semua permasalahan terjadi dari sisi motivasi ekstrinsik, intrinsik ataupun norma subyektif, akan tetapi terdapat hubungan dengan faktor lain didalamnya, hal tersebut dapat dijadikan mediasi bagi ketiga faktor utama. Variabel mediasi tersebut adalah sikap dan kepercayaan. Ketiga faktor tersebut akan menjadi mediator permasalahan atau pengaruh yang diberikan antara motivasi ekstrinsik, intrinsik dan norma subyektif terhadap niat untuk berbagi pengetahuan, sehingga akan memperjelas seberapa besar pengaruh yang disumbangkan.

\section{Tinjauan Pustaka}

Menurut Fen Lin (2007) motivasi ekstrinsik untuk berbagi pengetahuan adalah keyakinan hasil yang biasanya didasarkan pada persepsi karyawan dari nilai hubungan dengan pertukaran pengetahuan. Dalam konteks berbagi pengetahuan, biaya termasuk faktor yang berhubungan dengan upaya (misal waktu yang dibutuhkan, usaha mental) sedangkan potensi keuntungan termasuk menerima imbalan organisasi atau menciptakan kewajiban bagi rekan-rekan untuk membalas. Feng Lin (2007) yang menyimpulkan bahwa motivasi intrinsik mengacu terlibat dalam kegiatan untuk kepentingan sendiri, keluar dari ketertarikan, atau untuk kesenangan dan kepuasan yang berasal dari pengalaman. Ketertarikan, kesenangan ataupun kepuasan tidaklah cukup untuk menjadikan motivasi intrinsik sebagai salah satu dari faktor berbagi pengetahuan.

Penelitian Paliszkiewicz (2013) menyimpulkan bahwa kepercayaan didasarkan pada keyakinan bahwa orang mewakili dalam hubungan tanpa kekhawatiran tentang mengeksploitasi kerentanan. Kepercayaan antar pribadi adalah keadaan psikologis yang terdiri dari niat seseorang untuk menerima kerentanan terhadap tindakan pihak lain.

Ibragimova, et, al. (2012) norma subyektif dipandang sebagai kombinasi dari harapan dirasakan dari individu atau kelompok yang relevan bersama dengan niat untuk mematuhi harapan tersebut. Dengan kata lain, "persepsi 
orang bahwa kebanyakan orang yang penting bagi dia pikir dia harus atau tidak harus melakukan perilaku yang bersangkutan".

Menurut Mohsen et, al (2012) sikap didefinisikan sebagai perasaan positif atau negatif tentang menunjukkan perilaku tujuan. Sikap pribadi individu terhadap perilaku merupakan hasil dari kombinasi keyakinan sikap. Niat perilaku menunjukkan intensitas niat pribadi dan kemauan untuk melakukan tujuan perilaku.

Penelitian Shanshan (2013) menyatakan bahwa faktor-faktor yang mempengaruhi niat untuk berbagi pengetahuan oleh anggota orgaisasi termasuk sikap, iklim organisasi, self-efficacy, dan kualitas sistem informasi.
Hal itu perlu dilakukan agar dapat tercapainya organisasi.

\section{Metode Penelitian}

Penelitian ini menggunakan desain penelitian penjelasan dengan pendekatan kuantitatif. Penelitian ini dilaksanakan di SMP Muhammadiyah dan MTs Muhammadiyah Sekabupaten Sukoharjo. Variabel yang digunakan dalam penelitian ini adalah motivasi ekstrinsik, motivasi instrinsik, norma subyektif, kepercayaan, dan sikap terhadap niat untuk berbagi pengetahuan. Kerangka pemikiran dalam penelitian ini adalah sebagai berikut:

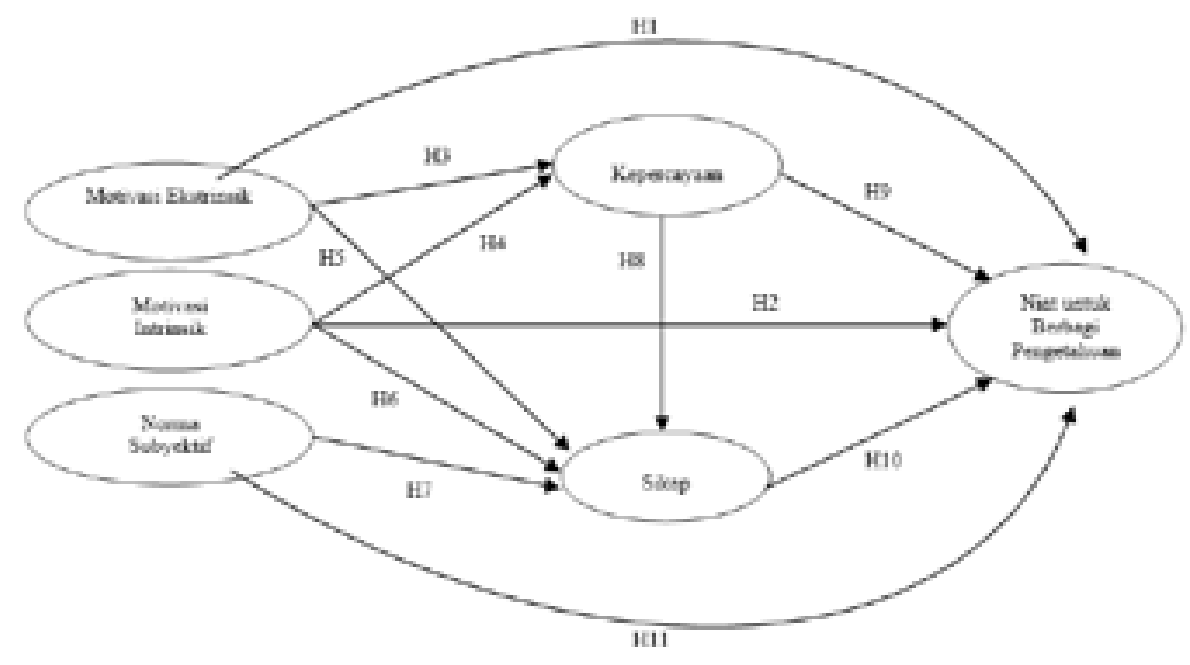

Gambar 1. Kerangka Pemikiran

Berdasarkan kajian teori dan penelitian terdahulu, hipotesis yang diajukan dalam penelitian ini adalah:

1. H1: Motivasi ekstrinsik berpengaruh terhadap niat untuk berbagi pengetahuan.

2. H2: Motivasi intrinsik berpengaruh terhadap niat untuk berbagi pengetahuan.

3. H3: Motivasi ekstrinsik berpengaruh terhadap kepercayaan.

4. H4: Motivasi intrinsik berpengaruh terhadap kepercayaan.

5. H5: Motivasi ekstrinsik berpengaruh terhadap sikap.

6. H6: Motivasi intrinsik berpengaruh terhadap sikap.

7. H7: Norma subyektif berpengaruh terhadap sikap.
8. H8: Kepercayaan berpengaruh terhadap sikap.

9. H9: Kepercayaan berpengaruh terhadap niat untuk berbagi pengetahuan.

10. H10: Sikap berpengaruh terhadap niat untuk berbagi pengetahuan.

11. H11: Norma subyektif berpengaruh terhadap niat untuk berbagi pengetahuan.

Populasi dalam penelitian ini adalah guru/pengajar SMP Muhammadiyah dan MTs Muhammadiyah Sekabupaten Sukoharjo, dengan sampel sebanyak 200 responden dengan teknik quota sampling. Instrumen penelitian untuk pengumpulan data dalam penelitian ini menggunakan kuesioner. Uji instrumen penelitian meliputi uji validitas dan 
uji reliabilitas. Teknik analisis menggunakan Structural Equation Modelling (SEM).

Sebelum model dilakukan maka perlu dilakukan test yang disebut dengan asumsi model dan analisis kesesuaian model Goodnes of Fit Test. Untuk mendapatkan model yang baik dan valid maka diperlukan beberapa asumsi. Uji goodnes of fit test model overal menggunakan uji Chi Square dengan tingkat toleransi $5 \%$. Proses perhitungan analisis data dilakukan dengan Software Amos 22. Ada pun langkah-langkah pada analisis SEM sebagai berikut:

1. Pengembangan model hipotetik yaitu merancang suatu model penelitian yang akan diuji secara statistik. Sebelumnya menggunakan model deskriptif yaitu model yang ditujukan untuk mendeskripsikan suatu konsep yang disebut measurement model.
2. Mengkrontruksi diagram jalur yang menggambarkan pola hubungan kausalitas antar variabel.

3. Mengkonversikan digram jalur yang telah digambar ke dalam model struktural.

4. Evaluasi dan intrepretasi hasil. Evaluasi model dilakukan dengan melihat beberapa kriteria pengujian seperti nilai regression weight, $t$ statistic dan koefisien determinasi.

\section{Hasil Dan Pembahasan}

Gambaran tentang karakteristik responden diperoleh dari data diri yang terdapat pada bagian depan kuesioner yaitu identitas responden yang meliputi usia, jenis kelamin, lama bekerja, dan status pekerjaan. Adapun deskripsi responden sebagai berikut:

Tabel 1.

Deskripsi Karakteristik Responden

\begin{tabular}{ccc}
\hline Karakteristik & Frekuensi & Persentase (\%) \\
\hline $25-25$ Tahun & Usia & $30 \%$ \\
$36-46$ Tahun & 72 & $36 \%$ \\
$47-57$ Tahun & 47 & $23,5 \%$ \\
$>58$ Tahun & 21 & $10,5 \%$ \\
& Jenis Kelamin & \\
Pria & 77 & $38,5 \%$ \\
Wanita & 123 & $61,5 \%$ \\
& Lama Bekerja & \\
$1-10$ Tahun & 60 & $30 \%$ \\
$11-20$ Tahun & 37 & $18,5 \%$ \\
$21-30$ Tahun & 69 & $34,5 \%$ \\
$>31$ Tahun & 34 & $17 \%$ \\
PNS & Status Pekerjaan & $25 \%$ \\
Non PNS & 50 & $75 \%$ \\
\hline
\end{tabular}

Sumber: Data Primer yang diolah, 2015

Berdasarkan Tabel 1 di atas dijelaskan bahwa sebagian besar responden berusia diantara 36-46 tahun, untuk jenis kelamin responden lebih banyak wanita yaitu sebanyak
123 orang atau $61,5 \%$ sedangkan pria sebanyak 77 orang atau 38,5\%. Berdasarkan masa kerja, sebagian besar responden bekerja selama kurun waktu 21-30 tahun, sedangkan 
untuk status pekerjaan non PNS lebih banyak dari pada yang berstatus PNS yaitu sebanyak 150 orang atau $75 \%$.

Tanggapan responden tentang motivasi ekstrinsik menunjukkan nilai rata-rata jawaban responden berkisar antara 3,54 sampai 4,42. Nilai rata-rata terendah pada item 'Saya akan menerima gaji yang lebih tinggi sebagai imbalan berbagi pengetahuan', sedangkan rata-rata tertinggi pada item 'Saya memperkuat hubungan antara saya dan guru di sekolah' dan 'Saya memperluas lingkup hubungan saya dengan guru lainnya'. Hal ini menunjukkan bahwa sebagian besar responden memiliki motivasi ekstrinsik yang tinggi.

Distribusi jawaban responden serta nilai rata-rata untuk item - item variabel motivasi intrinsik. Nilai rata-rata jawaban responden berkisar antara 3,57 sampai 4,38. Nilai rata-rata terendah pada item 'Saya yakin dengan kemampuan saya untuk memberikan pengetahuan, karena orang lain di sekolah menganggap saya mampu', sedangkan ratarata tertinggi pada item 'Saya senang berbagi pengetahuan dengan rekan guru lain'. Hal ini menunjukkan bahwa sebagian besar responden memiliki motivasi intrinsik yang tinggi.

Distribusi jawaban responden serta nilai rata-rata untuk item - item variabel norma subyektif. Nilai rata-rata jawaban responden berkisar antara 3,74 sampai 4,30. Nilai rata-rata terendah pada item 'Kebanyakan dari rekan guru percaya pada saya ketika saya berbagi pengetahuan dengan mereka', sedangkan rata-rata tertinggi pada item 'Rekan guru sangat penting bagi saya dalam berbagi pengetahuan'. Hal ini menunjukkan bahwa sebagian besar responden merasa berbagi pengetahuan dengan rekan kerja adalah penting.

Distribusi jawaban responden serta nilai rata-rata untuk item - item variabel sikap.
Nilai rata-rata jawaban responden berkisar antara 3,96 sampai 4,18. Nilai rata-rata terendah pada item 'Pengetahuan yang saya bagikan dengan guru lain dapat menimbulkan masalah', sedangkan rata-rata tertinggi pada item 'Pengetahuan yang saya bagikan dengan guru lain sangat berharga bagi saya'. Hal ini menunjukkan bahwa sebagian besar responden memiliki sikap yang baik mengenai berbagi pengetahuan.

Distribusi jawaban responden serta nilai rata-rata untuk item - item variabel kepercayaan. Nilai rata-rata jawaban responden berkisar antara 3,44 sampai 4,38. Nilai rata-rata terendah pada item 'Saya secara terbuka mengakui dan bertanggung jawab atas kesalahan yang kami perbuat', sedangkan rata-rata tertinggi pada item 'Adanya hubungan antara guru dengan guru yang baik'. Hal ini menunjukkan bahwa sebagian besar responden memiliki kepercayaan yang tinggi untuk berbagi pengetahuan dengan rekan kerja.

Distribusi jawaban responden serta nilai rata-rata untuk item - item variabel niat untuk berbagi pengetahuan. Nilai rata-rata jawaban responden berkisar antara 3,70 sampai 4,13. Nilai rata-rata terendah pada item 'Saya akan berbagi laporan pekerjaan saya dan dokumen resmi dengan guru lainnya lebih sering di masa yang akan datang', sedangkan rata-rata tertinggi pada item 'Saya akan mencoba untuk berbagi keahlian saya dari pendidikan saya atau pelatihan dengan guru lainnya dalam cara yang lebih efektif'. Hal ini menunjukkan bahwa sebagian besar responden memiliki niat yang tinggi untuk berbagi pengetahuan dengan rekan kerja.

Untuk menguji hipotesis dalam penelitian ini menggunakan metode Structural Equation Modeling (SEM) dengan AMOS 22. Hasil pengolahannya dapat dilihat pada Tabel 2 berikut: 
Tabel 2. Regression Weights

\begin{tabular}{lcccccc}
\hline & & & Estimate & S.E. & C.R. & P \\
\hline Kepercayaan & $<---$ & Motivasi Ekstrinsik & .184 & .059 & 3.105 & .002 \\
Kepercayaan & $<---$ & Motivasi Intrinsik & .475 & .085 & 5.573 & $* * *$ \\
Sikap & $<---$ & Motivasi Ekstrinsik & .162 & .074 & 2.200 & .028 \\
Sikap & $<---$ & Motivasi Intrinsik & .206 & .102 & 2.019 & .043 \\
Sikap & $<---$ & Kepercayaan & .224 & .107 & 2.098 & .036 \\
Sikap & $<---$ & Norma Subyektif & .177 & .076 & 2.315 & .021 \\
Niat untuk Berbagi & $<---$ & Motivasi Ekstrinsik & .042 & .078 & .537 & .591 \\
Pengetahuan & & & & & & \\
Niat untuk Berbagi & $<---$ & Motivasi Intrinsik & .040 & .110 & .360 & .719 \\
Pengetahuan & & & & & & \\
Niat untuk Berbagi & $<---$ & Kepercayaan & .321 & .122 & 2.626 & .009 \\
Pengetahuan & & & & & & \\
Niat untuk Berbagi & $<---$ & Norma Subyektif & .206 & .086 & 2.395 & .017 \\
Pengetahuan & & & & & & \\
Niat untuk Berbagi & $<---$ & Sikap & .376 & .140 & 2.687 & .007 \\
Pengetahuan & & & & & &
\end{tabular}

Sumber: Data primer yang diolah, 2015

Hasil pengujian pada Tabel 2 pengetahuan dan pengaruh motivasi intrinsik menunjukkan bahwa dari 11 jalur yang pada niat untuk berbagi pengetahuan. Hasil dianalisis, terdapat 2 jalur yang memiliki dari analisis pengaruh langsung (direct effect), hubungan yang tidak signifikan, terlihat dari pengaruh tidak langsung (indirect effect) dan besarnya tingkat signifikansi (p) uji hipotesis pengaruh total dari satu variabel terhadap yang lebih besar dari 5\%, yaitu pengaruh variabel lainnya dapat dilihat pada Tabel 3 motivasi ekstrinsik pada niat untuk berbagi berikut ini:

Tabel 3. Pengaruh Langsung, Tidak Langsung dan Total

\begin{tabular}{|c|c|c|c|c|}
\hline \multicolumn{2}{|c|}{ Variabel } & \multicolumn{3}{|c|}{ Pengaruh $(\beta)$} \\
\hline Independen & Dependen & Langsung & Tidak langsung & Total \\
\hline Motivasi Ekstrinsik & \multirow{2}{*}{ Kepercayaan } & 0,236 & - & 0,236 \\
\hline Motivasi Intrinsik & & 0,573 & - & 0,573 \\
\hline Motivasi Ekstrinsik & \multirow{5}{*}{ Sikap } & 0,203 & 0,052 & 0,255 \\
\hline Motivasi Intrinsik & & 0,244 & 0,126 & 0,370 \\
\hline Kepercayaan & & 0,220 & - & 0,220 \\
\hline Norma Subyektif & & 0,252 & - & 0,252 \\
\hline Motivasi Ekstrinsik & & 0,045 & 0,145 & 0,190 \\
\hline Motivasi Intrinsik & \multirow{4}{*}{$\begin{array}{l}\text { Niat untuk Berbagi } \\
\text { Pengetahuan }\end{array}$} & 0,040 & 0,273 & 0,313 \\
\hline Kepercayaan & & 0,269 & 0,071 & 0,340 \\
\hline Norma Subyektif & & 0,250 & 0,081 & 0,331 \\
\hline Sikap & & 0,321 & - & 0,321 \\
\hline
\end{tabular}

Sumber: Hasil olahan data, 2015 
Berdasarkan data pada Tabel 3 diketahui bahwa jalur yang memiliki pengaruh langsung yang paling besar adalah pengaruh motivasi intrinsik pada kepercayaan, yaitu sebesar 0,573 dan pengaruh tidak langsung yang paling besar adalah pengaruh motivasi intrinsik pada niat untuk berbagi pengetahuan sebesar 0,273.

\section{Pengaruh Motivasi Ekstrinsik dan Motivasi Intrinsik pada Niat untuk Berbagi Pengetahuan}

Hasil analisis jalur pada Tabel 2 menunjukkan nilai CR motivasi ekstrinsik pada niat untuk berbagi pengetahuan sebesar 0,537 dengan tingkat signifikansi 0,591 dan nilai CR motivasi intrinsik pada niat untuk berbagi pengetahuan sebesar 0,360 dengan tingkat signifikansi 0,719 , sehingga hipotesis 1 dan 2 tidak didukung dalam penelitian ini. Fenomena ini dapat terjadi karena seorang guru yang memiliki motivasi ekstrinsik dan motivasi intrinsik untuk berbagi pengetahuan belum tentu memiliki niat untuk melakukan berbagi pengetahuan. Hasil penelitian ini bertentangan dengan penelitian yang dilakukan oleh Zhang (2011), dalam penelitiannya menunjukkan bahwa setiap individu mempunyai nilai sosial yang cukup tinggi untuk mencapai penghargaan (reward) melalui berbagi pengetahuan terhadap sesama karyawan. Pendapat maupun hasil penelitian tersebut menunjukkan bahwa adanya nilai sosial yang besar disetiap individu-individu manusia, namun kenyataannya yang terjadi pada guru SMP Muhammadiyah dan MTs Muhammadiyah Sekabupaten Sukoharjo belum semuanya yang memiliki motivasi ekstrinsik maunpun intrinsik sanggup melaksanakan berbagi pengetahuan terhadap sesama guru.

Menurut penelitian dari Fen Lin (2007), motivasi ekstrinsik karyawan untuk berbagi pengetahuan adalah hasil keyakinan yang biasanya didasarkan pada persepsi karyawan dari nilai hubungan dengan berbagi pengetahuan. Motivasi eksitrinsik sangat berpengaruh terhadap niat untuk berbagi pengetahuan. Hasil tersebut bertolak belakang dengan penelitian saat ini, kurang adanya keyakinan pada diri seorang guru untuk melakukan berbagi pengetahuan pada sesama guru lainnya menjadi faktor penghalang. Perlu adanya penindak lanjutan dengan penelitian saat ini, faktor apa saja yang dapat mempengaruhi seorang guru untuk membagi penalamannya.

Berdasarkan pembahasan di atas, pada kenyataannya para guru dirasa kurang aktif dalam berbagi pengetahuan, hal tersebut menjadi bahan renungan bagi setiap guru guna mengevaluasi seluruh aktivitasnya guna meluangkan waktuuntuk berbagi pengetahuan. Minimnya waktu untuk berinteraksi langsung dengan para guru guna membahas hal tersebut menjadi titik lemah penelitian ini. Sehingga perlu adanya kuesioner tambahan mengenai psikologi para guru SMP Muhammadiyah dan MTS Muhammadiyah sekabupaten Sukoharjo, mengenai pelaksanaan atau kegiatan berbagi pengetahuan.

\section{Pengaruh motivasi ekstrinsik dan motivasi intrinsik pada kepercayaan}

Dari hasil analisis jalur menunjukkan nilai CR motivasi ekstrinsik pada kepercayaan sebesar 3,105 dengan tingkat signifikansi 0,002 dan nilai $\mathrm{CR}$ motivasi intrinsik pada kepercayaan sebesar 5,573 dengan tingkat signifikansi 0,000 . Hasil tersebut menunjukkan adanya pengaruh positif antara motivasi ekstrinsik dan motivasi intrinsik pada kepercayaan, sehingga hipotesis 3 dan 4 didukung dalam penelitian ini. Fenomena ini dapat terjadi karena seorang guru yang memiliki motivasi ekstrinsik dan motivasi intrinsik untuk berbagi pengetahuan maka akan meningkatkan kepercayaan guru tersebut mengenai perilaku berbagi pengetahuan.

Pelaksanaan berbagi pengetahuan di kalangan guru SMP Muhammadiyah dan MTS Muhammadiyah sekabupaten Sukoharjo akan menimbulkan rasa kepercayaan pada diri guru tersebut, pada kenyataannya sebagai contoh guru di MTs Muhammadiyah Blimbing telah beberapa kali membagikan ilmunya untuk 
guru lain dalam hal bimbingan guru muda. Rasa percaya diri setiap guru akan meningkat sejalan dengan adanya motivasi baik dari dalam (yaitu niat) maupun dari luar untuk berbagi pengetahuan terhadap rekan kerja.

Hasil penelitian ini mendukung penelitian yang dilakukan oleh Osmani et al., (2014), yang menyatakan bahwa pekerja akan lebih percaya pada kemampuan mereka setelah mereka mempersiapkan ilmu pengetahuannya untuk melakukan tugastugas khusus dan penelitian dari John, et al (1985), hubungan antara motivasi ekstrinsik terhadap hubungan psikologi (termasuk rasa percaya dan cinta) merupakan hubungan yang penting dalam berorganisasi, karena adanya saling keterkaitan diantaranya. Hal tersebut senada dengan penelitain saat ini, dimana rasa kepercayaan pada diri sendiri akan semakin meningkat jika telah melakukan tanggungjawabnya sebagai orang yang memiliki ilmu lebih dan merelakan waktunya untuk berbagi pengetahuan. Sebenarnya berbagi ilmu tidaklah mengurangi wawasan kita akan ilmu tersebut, justru menjadikan ilmu atau pengetahuan yang kita miliki akan semakin bertambah. Kepercayaan diri seorang guru dapat membawanya pada sebuah pencapaian tertinggi, wawasan keilmuan yang dimiliki akan semaikin berkembang dan bermanfaat bagi banyak orang.

\section{Pengaruh Motivasi Ekstrinsik dan Motivasi Intrinsik pada Sikap}

Hasil analisis jalur menunjukkan nilai CR motivasi ekstrinsik pada sikap sebesar 2,200 dengan tingkat signifikansi 0,028 dan motivasi intrinsik pada sikap sebesar 2,019 dengan tingkat signifikansi 0,043. Hasil tersebut menunjukkan adanya pengaruh positif antara motivasi ekstrinsik dan motivasi intrinsik pada sikap, sehingga hipotesis 5 dan 6 didukung dalam penelitian ini. Fenomena ini dapat terjadi karena seorang guru yang memiliki motivasi ekstrinsik dan motivasi intrinsik untuk berbagi pengetahuan maka akan meningkatkan sikap positif guru tersebut mengenai perilaku berbagi pengetahuan.
Sebagaimana dengan rasa percaya diri yang dimiliki guru setelah adanya motivasi ekstrinsik dan intrinsik mengenai berbagi pengetahuan, maka hal tersebut juga terjadi pada sikap positif guru tersebut mengenai perilaku berbagi pengetahuan. Hasil penelitian ini mendukung penelitian yang dilakukan oleh Lin (2007), yang menyatakan bahwa sikap positif karyawan mengenai perilaku berbagi pengetahuan berawal dari motivasi pekerja itu sendiri. Selain itu ada penelitian dari Abduljalil dan Zainuddin (2015), dalam mengatur sikap atau tingkah laku, pemimpin harus mengenalkan tentang pentingnya motivasi. Motivasi dari luar (ekstrinsik) merupakan bagian terpenting guna mencapai tujuan dan hal ini mempengaruhi terhadap sikap atau tingkah laku pekerja.

Penelitian dari Mohsen (2012), melihat dari sudut perspektif motivasi intrinsik, sikap merupakan kompetensi atau kebutuhan karyawan untuk menunjukkan kepribadian mereka. Sikap ini dapat membantu karyawan lain untuk mencapai tujuan bersama. Karyawan yang memiliki sikap positif maka dapat memotivasi untuk meningkatkan kinerja mereka di perusahaan. Sepertihalnya motivasi ekstrinsik, motivasi intrinsik memiliki makna tersendiri dari penelitian sebelumnya. Hasil tersebut sejalan dengan hasil penelitian saat ini yang menyatakan bahwa motivasi intrinsik dapat meningkatkan sebuah kepribadian baik bagi guru. Sikap disini adalah tingkah laku maupun tindakan guru dalam niatnya untuk berbagi pengetahuan pada guru lain.

\section{Pengaruh Norma Subyektif dan Kepercayaan pada Sikap}

Hasil analisis jalur pada Tabel 2 menunjukkan nilai $\mathrm{CR}$ norma subyektif pada sikap sebesar 2,315 dengan tingkat signifikansi 0,021 dan nilai CR kepercayaan pada sikap sebesar 2,098 dengan tingkat signifikansi 0,036 . Kedua pengaruh tersebut menunjukkan adanya pengaruh positif yang diberikan norma subyektif dan kepercayaan pada sikap, sehingga hipotesis 7 dan 8 didukung dalam penelitian ini. Fenomena 
ini dapat terjadi karena seorang guru yang memiliki norma subyektif dan kepercayaan bahwa berbagi pengetahuan itu baik maka akan meningkatkan sikap positif guru tersebut mengenai perilaku berbagi pengetahuan.

Hasil penelitian tentang norma subyektif ini mendukung penelitian yang dilakukan oleh Nikdavoodi (2012), yang menyatakan bahwa norma subyektif mempengaruhi tingkah laku atau sikap karyawan yang berhubungan dengan kinerja dalam berorganisasi. Denga adanya hubungan atau keterkaitannya, norma subyektif dan tingkah laku atau sikap mampu memberikan persepsi yang lebih baik. Selain itu dalam penelitian dari Kholoud (2015), membuktikan bahwa norma subyektif merupakan persepsi setiap individu terhadap sikap atau tingkah laku individu lain. Sikap individu sangat ditentukan oleh pemikiran atau norma subyektif karyawan.

Kepercayaan memiliki pengaruh pada tindakan guru, dimana hasil tersebut memiliki kesamaan dengan penelitian dari Ibragimova et al., (2012), Jik dan James (2009) dan Osmani et al. (2014). Dari ketiga penelitian terdahulu tersebut menunjukkan adanya pengaruh yang diberikan kepercayaan karyawan terhadap sikap untuk melakukan suatu tindakan. Dalam penelitian tersebut juga menyatakan bahwa kepercayaan dan perilaku memiliki hubungan timbal balik yang dapat memperkuat satu sama lain. Manfaat timbal balik secara signifikan terkait dengan membangun kepercayaan yang memungkinkan berpengaruh terhadap sikap atau perilaku. Sehingga dapat disimpulkan dari beberapa penelitian terdahulu bahwa norma subyektif dan kepercayaan memiliki pengaruh poitif terhadap sikap pekerja, sedangkan dalam penelitian saat ini sikap yang dimaksut adalah tingkah laku maupun tindakan guru dalam niatnya untuk berbagi pengetahuan pada guru lain. Sehingga norma subyektif dan kepercayaan memiliki pengaruh positif terhadap sikap atau tindakan guru dalam niatnya untuk berbagi pengetahuan.

\section{Pengaruh Kepercayaan, Sikap, dan Norma Subyektif pada Niat untuk Berbagi Pengetahuan}

Berdasarkan hasil dari Tabel 2 diketahui bahwa kepercayaan memiliki nilai CR pada niat untuk berbagi pengetahuan sebesar 2,626 dan nilai signifikansi sebesar 0,009, sedangkan sikap memiliki nilai CR pada niat untuk berbagi pengetahuan sebesar 2,687 dan nilai signifikansi sebesar 0,007 dan norma subyektif memiliki nilai CR pada niat untuk berbagi pengetahuan sebesar 2,395 dan nilai signifikansi sebesar 0,017 .

Hasil di atas dapat disimpulkan bahwa pengaruh kepercayaan, sikap, dan norma subyektif berpengaruh positif pada niat untuk berbagi pengetahuan, sehingga hipotesis 9, 10, dan 11 didukung dalam penelitian ini. Fenomena ini dapat terjadi karena seorang guru yang memiliki kepercayaan dan sikap bahwa berbagi pengetahuan itu baik maka akan meningkatkan niat guru tersebut untuk berbagi pengetahuan dengan sesama rekan kerjanya. Hasil penelitian ini mendukung penelitian yang dilakukan oleh Tan, (2011); Osmani et al., (2014); Ali, et, al (2013); Fen Lin (2007); Chen et, al (2009); Mohsen et, al (2012); Ibragimova et al., (2012); dan Shanshan (2013).

Kepercayaan diri seorang guru memiliki pengaruh pada niat guru untuk berbagi pengetahuan, hasil tersebut sama halnya dengan penelitian dari Tan (2011) dan Osmani et al., (2014) yang menyebutkan bahwa ketika kepercayaan datang, maka setiap individu tidak akan melukai satu sama lain, sebaliknya mereka akan berbagi pengetahuan satu dengan lainnya. Selain itu kepercayaan sebagai salah satu faktor dari berbagi pengetahuan yang melalui tingkah laku anggota organiasi yang mendukung atau memfasilitasi berbagi pengetahuan.

Tindakan atau sikap guru memiliki pengaruh positif terhadap niat untuk berbagi pengetahuan, hasil tersebut menjadi penguat 
pada penelitian terdahulu dari Ali, et, al (2013) yang menyatakan bahwa ketika seseorang membagi pengetahuannya, hal ini berarti seseorang itu telah meneruskan pengetahuan orang lain secara langsung, dan terus membantu menyebarkan pengetahuan secara lebih baik. Penelitian dari Fen Lin (2007) berpendapat bahwa sikap secara signifikan sangat berpengaruh terhadap tingkah laku karyawan. Selanjutnya, sikap individu karyawan juga berpengaruh terhadap niat untuk berbagi pengetahuan. Sehingga tindakan yang dilakukan untuk melakukan sesuatu dapat membantu dalam penyebaran pengetahuan ke obyek yang lebih luas.

Norma subyektif merupakan reaksi atau hasil dari tindakan seseorang, dimana norma subyektif mempberikan pengaruh positif terhadap niatan guru untuk berbagi pengetahuan. Hasil tersebut menjadi penguat bagi penelitian sebelumnya dari Chen et, al (2009), yang menyatakan bahwa hubungan norma subyektif terhadap niat untuk berbagi pengetahuan menunjukkan pengaruh yang cukup signifikan. Selain itu penelitian dari Mohsen et, al (2012), yang menunjukkan bahwa norma subjektif juga penting dalam berbagi pengetahuan. Suasana organisasi yang positif mempengaruhi pembentukan norma subjektif dan akibatnya mempengaruhi niat individu untuk berbagi pengetahuan.

\section{Penutup}

Berdasarkan hasil analisis yang telah penulis uraikan dengan menggunakan metode analisis Structural Equation Modeling (SEM) dapat diambil kesimpulan bahwa: Motivasi ekstrinsik dan motivasi intrinsik tidak berpengaruh pada niat untuk berbagi pengetahuan. Motivasi ekstrinsik dan motivasi intrinsik berpengaruh pada sikap dan kepercayaan. Kepercayaan dan norma subyektif berpengaruh pada sikap. Kepercayaan, sikap, dan norma subyektif berpengaruh pada niat untuk berbagi pengetahuan.

Penulis memberikan beberapa saran yaitu (1) bagi lembaga terkait, hasil penelitian ini mungkin dapat dijadikan pembelajaran dalam membangun sebuah organisasi yang baik dan kuat untuk kedepannya. Karena dari berbagai aspek maupun faktor yang dijadikan sebagai variabel dapat menjadi bahan evaluasi lembaga, misalnya motivasi yang berperan penting dalam membantu meningkatkan rasa percaya diri dan sikap untuk berbagi pengetahuan. Norma subyektif sebagai harapan dari setiap individu untuk memberikan andil dalam memajukan/ memperkaya konsep atau teori perkembangan ilmu pengetahuan dalam bidang manajemen secara luas. (2) Bagi para akademisi hasil penelitian ini dapat dimanfaatkan sebagai sumbangan untuk mengembangkan ilmu pengetahuan, khususnya dalam bidang pendidikan dan manajemen sekolah maupun lembaga. Karena dengan motivasi baik dari luar maupun dalam dan adanya norma subyektif yang berupa harapan yang dirasakan para guru maupun karyawan instansi dapat menciptakan suasana nyaman dan kondusif. Dalam hal ini yang dimaksud nyaman dan kondusif adalah lingkungan yang mendukung untuk bertukar pikiran maupun pengetahuan. Serta (3) bagi peneliti selanjutnya dapat dijadikan sebagai referensi guna mengetahui tingkat sikap, kepercayaan maupun niat untuk berbagi pengetahuan. Selain itu tidak hanya faktor motivasi dan norma subyektif yang dapat dijadikan sebagai pengaruh bagi variabel dependennya.

\section{Daftar Pustaka}

Abduljalil, Khalil dan Zainuddin, Yuserrie. 2015. "Intrinsic and Extrinsic as Attitude Factors towards Adoption of Accounting Information System (AIS) in Libyan SMEs.". International Journal of Academic Research in Accounting, Finance and Management Sciences. Vol. 5, No. 1, January 2015, pp: 161-170. 
Ali, Nasr Isfahani, Akbar Nilipour, Tahereh Aghababapour, dan Mohammad Hasan Tanhaei. 2013. "Studying the Impact of Attitude towards Knowledge Sharing on Employee' Happiness (Case Study: Employees of University of Isfahan)." International Journal of Academic Research in Business and Social Sciences. April 2013, Vol. 3, No. 4.

Casebourne, Jo. 2014. Motivation Matters in Public Sector Innovation. London: Plough Place, London, EC4A 1DE.

Chen, I. Y, L., Nian Shing Chen dan Kinshuk. 2009. "Examining the Factors Influencing Participants' Knowledge Sharing Behavior in Virtual Learning Communities." Educational Technology \& Society. Vol. 12, No. 1, pp: 134-148.

Fen, Hsiu Lin. 2007. "Effects of extrinsic and intrinsic motivation on employee knowledge sharing intentions". Journal of Information Science 2007. Vol. 33, No. 135 originally published online 15 October 2007.

Gagne, Marylene; Jacques, Forest; Maarten, Vansteenkiste; Laurence, Crevier-Braud; Anja, van den Broeck; Ann, Kristin, Aspeli; Jenny, Bellerose; Charles; Benabou; Emanuela; Chemolli, Stefan, Tomas, Güntert; Hallgeir, Halvari; Devani, Laksmi, Indiyastuti; Peter, A., Johnson; Marianne, Hauan, Molstad; Mathias, Naudin; Assane, Ndao; Anja, Hagen, Olafsen; Patrice, Roussel; Zheni, Wang; dan Cathrine, Westbye. 2015. "The Multidimensional Work Motivation Scale: Validation evidence in seven languages and nine countries". European Journal of Work and Organizational Psychology. Vol. 24, No. 2, pp: 178-196.

Gee, Woo Back, Robert W. Zmud, Young Gul Kim, dan Jae Nam Lee. 2005. "Behavioral Intention Formation in Knowledge Sharing: Examining the Roles of Extrinsic Motivators, Social-Psychological Forces, and Organizational Climate". MIS Quarterly, Vol. 29, No. 1, pp. 87-111.

Hartono; Laksmi, Asri, Riani; dan Suhardjanto, Djoko. 2014. Panduan Penulisan Proposal dan Tesis. Magister Manajemen Fakultas Ekonomi dan Bisnis. Surakarta: UNS.

I. Kholoud, Al Qeisi dan Hanadi M. Al Zagheer. 2015. "Determinants of Knowledge Sharing Behaviour among Personnel in Banking Industry". International Journal of Business and Management. Vol. 10, No. 4, pp: 49-59.

Ibragimova, Bashorat, Shery D. Ryan, John C. Windsor dan Victor R. Prybutok. 2012. Understanding the Antecedents of Knowledge Sharing: "An Organizational Justice Perspective". The International Journal of an Emerging Transdiscipline. Vol. 15, pp: 183-205.

Jik, Yoon, Cho dan James L. Perry." Employee Motivations, Managerial Tustworthiness, and Work Attitudes". Management Research Association Conference, Columbus, OH, October 1-3, 2009.

Luo, Zhenshan, Jan Grundling dan Lizl Steynberg. 2013. "Attitudes, Subjective Norms and Behavioural Control Towards Traditional Chinese Medicine in South Africa". Proceedings of 8th Annual London Business Research Conference Imperial College, London, UK, 8 - 9 July, 2013.

M. Richard, Ryan dan Edward L. Deci. 2000. "Intrinsic and Extrinsic Motivations: Classic Definitions and New Directions". Contemporary Educational Psychology. Vol. 25, pp: 54-67.

Mafini, Chengedzai dan Nobukhosi Dlodlo. 2014. "The relationship between extrinsic 
motivation, job satisfaction and life satisfaction amongst employees in a public organization". SA Journal of Industrial Psychology/SA Tydskrif vir Bedryfsielkunde. Vol. 40, No. 1, Art. \#1166, 13 pages.

Mohsen, Sayyed Allameh, Ahmad Abedini, Javad Khazaei Pool, dan Ali Kazemi. 2012. "An analysis of factors affecting staffs knowledge sharing in the central library of the University of Isfahan using the extension of Theory of Reasoned Action." International Journal of Human Resource Studies. Vol. 2. No. 1.

Osmani, Mohammad, Abd Rozan Mohd Zaidi, dan Mehrbakhsh Nilashi. 2014. "Motivational Factors, Trust and Knowledge Sharing in Organizations." International Journal of Innovation and Scientific Research. Vol. 12, No. 2, pp. 463-474.

Paliszkiewicz, Joanna. 2013. "Organizational trust as a foundation for knowledge sharing and its influence on organizational performance". Online Journal of Applied Knowledge Management A Publication of the International Institute for Applied Knowledge Management. Vol. 1, No. 2.

Shahzadi, Irran, Raja Mazhar dan Abdul Rauf Kashif 2015. "Individual Motivational Factors of Optimistic Knowledge Sharing Behavior among University Academia". The Business \& Management Review. Vol. 6, No. 1.

Shanshan, Shang. 2013. "An Integrated Model on Factors Influencing Knowledge Sharing”. International Journal of Digital Content Technology and its Applications (JDCTA). Vol. 7, No. 9.

Sugiyono. 2012. Metode Penelitian Kombinasi (Mixed Methods). Bandung: CV Alfabeta.

Tan, Christine Nya Ling. 2011."Cultur and Trust in Foresting Knowledge Sharing." Journal of Knowledge Management. Vol. 9, No. 4, pp: 328-339.

Wang, Chee Kent Kam dan Su Ann Liew. 2015. "Determinants of Knowledge Sharing Culture in Malaysian Technology Firms." Proceedings of 8th Asia-Pacific Business Research Conference 9-10 February 2015, Hotel Istana, Kuala Lumpur, Malaysia.

Zhang, Xi. 2011. "Cultural Influences on Explicit and Implicit Knowledge Sharing Behaviour in Virtual Teams". International Journal of Computer Science \& Information Technology (IJCSIT). Vol. 3, No. 4, August 2011. 